\title{
Enantiomertiszta fluoreszcens szenzormolekulák előállítása és vizsgálata ${ }^{\dagger}$
}

\author{
PÁL Dávid, MÓCZÁR Ildikó és HUSZTHY Péter* \\ Budapesti Müszaki és Gazdaságtudományi Egyetem, Vegyészmérnöki és Biomérnöki Kar, \\ Szerves Kémia és Technológia Tanszék, Szent Gellért tér 4., 1111 Budapest, Magyarország
}

\section{Bevezetés}

A molekuláris felismerés jelenségének müködése során egy gazdamolekula az öt körülvevő molekulahalmazból kiválaszt egy vendégmolekulát, és intermolekuláris másodlagos kötőerőkkel összetartott komplexet alkot vele. Példa erre az enzimek müködése. Emil Fischer az enzimek specifikus szubsztrátfelismerését a zár és a kulcs kapcsolatához hasonlította. ${ }^{1}$ Elméletének felismerési mechanizmusa lelhető fel egy általános receptor vendégmolekulával alkotott komplexében.

Enantiomerfelismerés alatt azt a jelenséget értjük, amikor egy királis gazdamolekula eltérő kölcsönhatásba lép egy királis vendégmolekula két enantiomerjével. Az enantiomerfelismerés a természetben gyakran elöforduló létfontosságú jelenség. Kiemelendő, hogy az aminosavak és a cukrok enantiomertiszta formában fordulnak elő a biokémiai folyamatokban. Mivel a biológiailag aktív királis molekulák egyes enantiomerjei eltérő élettani hatást fejthetnek ki, nagy jelentőséggel bír a királis szerves vegyületek enantiomerösszetételének meghatározása. Az enantiomerfelismerés viszonylag egyszerü szintetikus gazdamolekulákkal is megvalósítható. Az ilyen jellegü kutatások eredményeként olyan új enantiomerszelektív szenzormolekulák fejleszthetők ki, amelyek jól alkalmazhatók enantiomerösszetétel meghatározására.

Egy királis gazdamolekula egy királis vendégmolekula enantiomerjeivel diasztereomer komplexeket alkot, amelyek eltérö fizikai tulajdonságai megkülönböztetést tesznek lehetővé. Pirkle és Pochapsky az enantiomerfelismerés feltételeként a „hárompontos szabályt" fogalmazta meg. ${ }^{2}$ A szabály szerint a gazdamolekula és legalább az egyik vendégmolekula között három különböző, egyidejüleg fellépő másodlagos kölcsönhatás szükséges, amelyek közül legalább az egyiknek sztereokémia-függőnek kell lennie. Az 1 gazdamolekula jól illeszkedik a 2 vendégmolekulához, de nem illeszkedik jól a $\mathbf{3}$ vendégmolekulához (1.A ábra). Az 1 gazdamolekula és a 3 vendégmolekula kölcsönhatása esetén a két szaggatott vonallal jelölt kölcsönhatás melletti harmadik, C…' ' kölcsönhatás határozza meg az enantiomerszelektivitást (1.B ábra). Ez a harmadik kölcsönhatás a leggyengébb a három másodlagos kötés közül, és a legtöbb esetben valószínüleg nem képvisel nagy energiakülönbséget. ${ }^{3}$
A
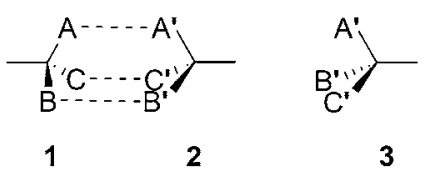

3

1. Ábra. Az 1 gazdamolekula és a 2 enantiomer által alkotott komplex, illetve a $\mathbf{3}$ enantiomer (A), valamint az $\mathbf{1}$ gazdamolekula és a $\mathbf{3}$ enantiomer által alkotott komplex szerkezete $(\mathbf{B})^{3}$

A molekulatársulások kémiájával egy viszonylag fiatal tudományterület, a szupramolekuláris kémia foglalkozik. $\mathrm{Az}$ első szintetikus gazdamolekulákat, a koronaétereket Pedersen fedezte fel 1967-ben. ${ }^{4}$ Kiemelkedő komplexképző tulajdonságuk okán a kutatások később kiterjedtek változatos szerkezetü koronaéterek és más típusú receptorok, köztük különböző fémionok, szerves kationok, anionok és enantiomerek felismerésére képes származékok előállítására és vizsgálatára is. ${ }^{3}$

$\mathrm{Az}$ enantiomertiszta anionreceptorokban leggyakrabban aminosav, BINOL, szteroid vagy monoszacharid egységek a kiralitás hordozói, de a kiralitás forrásaként alkalmazták többek között az 1-ariletil egységeket ${ }^{5-9}$ is. Ezen szenzormolekulák gyakran tartalmaznak karbamid és tiokarbamid receptor egységeket, amelyek jó hidrogénkötés-donor tulajdonságuk miatt nagy affinitást mutatnak anionok megkötésére. ${ }^{10}$ Korábban előállítottunk egy bisz(tiokarbamid) típusú királis anionszenzort, és tanulmányoztuk az enantiomerfelismerő-képességét. ${ }^{11}$

A koronaéterek enantiomerszelektivitását elsőként Cram és munkatársai tanulmányozták, akik bisz(binaftil)-22-korona-6-éter-származékok protonált primer aminok enantiomerjeivel szemben mutatott szelektivitását vizsgálták. ${ }^{12}$ Úttörő munkájuk óta számos enantiomertiszta koronaétert állítottak elő, és többféle módszerrel tanulmányozták azok enantiomerfelismerő-képességét. Az aza-18-korona-6-éterek kitűnő gazdamolekuláknak bizonyultak szerves primer ammónium-ionok számára. Közülük a piridin egységet tartalmazó koronaéterek az aromás gyürünek és a nitrogénatomnak köszönhetően kiemelkedő komplexképzési tulajdonságot mutattak protonált primer aminokkal szemben. ${ }^{13}$

A fluoreszcencia spektroszkópia szelektivitása és érzékenysége miatt változatos szerkezetű optikailag aktív fluoreszcens szenzormolekulákat fejlesztettek ki. ${ }^{10,14}$ Egyes fluoreszcens szenzormolekulák nagymértékü fluoreszcen-

\footnotetext{
† Pál Dávid azonos című PhD értekezéséhez kapcsolódó Tézisfüzet alapján készült.

*Tel.: +36 1463 1071; fax: +36 1463 3297; e-mail: huszthy@mail.bme.hu
} 


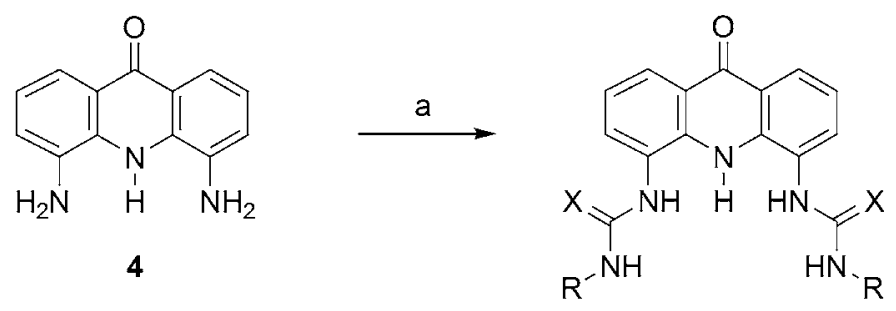

$(S, S)-6: X=O, R=$ $(S, S)-7: X=S, R=$<smiles>CC(C)c1ccccc1</smiles><smiles>CC(C)(C)c1cc(N)c2c(c1)S(=O)(=O)c1cc(C(C)(C)C)cc(N)c1N2</smiles><smiles>[R]NC([X])Nc1cc(C(C)(C)C)cc2c1Nc1c(NC([X])N[R])cc(C(C)(C)C)cc1S2(=O)=O</smiles>

$(S, S)-8: X=0, R=$ $(S, S)-9: X=S, R=$<smiles>CC(C)C(C)(C)c1ccccc1</smiles>

$(S, S)-10: X=O, R=$ $(S, S)-11: X=S, R=$<smiles>CC(C)c1cccc2ccccc12</smiles>

2. Ábra. Új anionszenzorok szintézise (a: $\mathrm{R}-\mathrm{N}=\mathrm{C}=\mathrm{X}, \mathrm{DMF}, 28 \%, 27 \%$; b: $\mathrm{R}-\mathrm{N}=\mathrm{C}=\mathrm{X}$, piridin, $50-77 \%$ )

cia intenzitásnövekedést mutatnak kation koordinálásakor (off-on karakterisztika). ${ }^{15-17}$ Egy optikai jelenség, jelen esetben a fluoreszcencia szabályozható ki- és bekapcsolhatósága nemcsak szenzormolekulák tervezését teszi lehetővé, hanem molekuláris logikai kapuk és azokat alkalmazó információ-feldolgozásra képes eszközök megvalósításának elvi alapját is képezheti. ${ }^{15}$

Fémionok analízise esetén a fluoreszcens szenzormolekulák kiemelt fontosságát többek között az orvosi diagnosztikában és a nehézfém-szennyezések nyomonkövetésében történő alkalmazási lehetőségük adja. ${ }^{15-23}$ Az anionok egyaránt fontos szerepet játszanak számos kémiai és biológiai folyamatban. Egyes kation- és/vagy anionszenzorok molekuláris felismerőképessége megfelelő vegyi anyagok mint bemenetek alkalmazása és az abszorpció vagy a fluoreszcencia emissziós intenzitás kimenetként történő detektálása esetén felhasználható Boole-féle logikai müveletek, például AND (ÉS), OR (VAGY), XOR (KIZÁRÓ VAGY), NAND (NEM-ÉS), NOR (NEM-VAGY), XNOR (KIZÁRÓ NEMVAGY), IMP (IMPLIKÁCIÓ) és INH (INHIBÍCIÓ) kapuk utánzására. Emellett többféle szakirodalomban közölt szenzormolekula képes a logikai kapuk integrálása révén öszszetettebb logikai müveletek végrehajtására. A kapott molekuláris logikai hálózatok között szerepelnek a félösszeadó, félkivonó és összehasonlító integrált logikai müveletek. ${ }^{24}$

Munkánk során olyan enantiomertiszta fluoreszcens szenzormolekulák előállításával és vizsgálatával foglalkoztunk, amelyek enantiomerfelismerő-képességet vagy szelektív ionfelismerést mutathatnak, így alkalmasak lehetnek optikai szenzorban történő felhasználásra. A receptorok fluoreszcens jelzőegységeként akridon, 5,5-dioxofenotiazin, benzotiazol vagy pirén fluorofort alkalmaztunk. A deprotonált karbonsav enantiomerek, valamint a protonált pri- mer aminok és aminosav-észter enantiomerek megkülönböztetése azért előnyös, mert ezen molekulák fiziológiás körülmények között ilyen formájukban fordulnak elő. Az elöállított receptorok komplexképzési tulajdonságait ezért az előbbi királis ionos vendégmolekulákkal, emellett egy esetben fémionokkal és akirális anionokkal szemben is tanulmányoztuk.

\section{Eredmények}

\section{1. Új vegyületek előállítása}

A 4 és 5 diaminokat a megfelelő izocianátokkal és izotiocianátokkal acilezve az $(S, S)$-6 és $(S, S)$-7 akridonszármazékokat, valamint az $(S, S)-8-(S, S)-11$ fenotiazinszármazékokat nyertük (2. ábra). ${ }^{25,26}$ A 4 diamint a megfelelö dinitrovegyületből a szakirodalomban közölt módszereknél hatékonyabban, katalitikus hidrogénezéssel állítottuk elő. ${ }^{25}$

A 12 akridondikarbonsavat katalitikus mennyiségü $N, N$ dimetilformamid jelenlétében tionil-kloriddal reagáltattuk, majd a kapott nyersterméket $(S)$-leucin-metilészter-hidrogén-kloriddal trietil-amin jelenlétében tetrahidrofuránban vittük reakcióba. Az acilezést követően a nyerstermék hidrolízisével kaptuk az $(S, S)$-13 akridonszármazékot (3. ábra). ${ }^{27}$

Az $(S, S)-14-(S, S)$-16 benzotiazol egységet tartalmazó új piridino-koronaéter-származékokat a 4. és 5. ábrán bemutatott szintézisutakon keresztül állítottuk elö. ${ }^{27}$

Az $(S, S)-17$ butilamino-csoportot tartalmazó enantiomertiszta piridino-koronaéter és 2-klórbenzotiazol nátrium-hidrid jelenlétében végbemenő reakciójával tetrahidrofurán és $N, N$-dimetilformamid elegyében jutottunk 


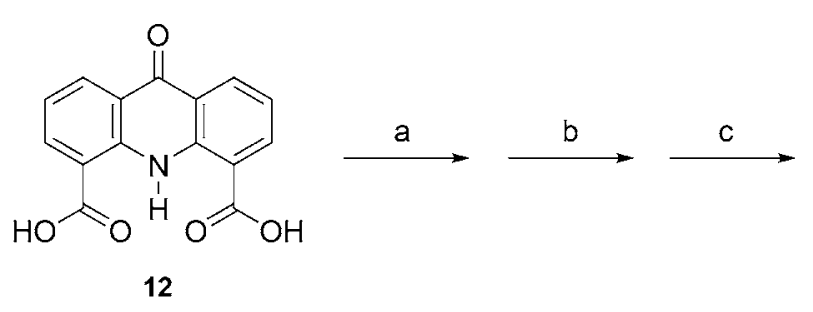<smiles>COC(=O)C(C)NC(=O)c1cccc2c(=O)c3cccc(C(=O)NC(CC(C)C)C(=O)OC)c3[nH]c12</smiles>

$(S, S)-13$

3. Ábra. $\mathrm{Az}(S, S)$-13 új szenzormolekula szintézise [a: $\mathrm{SOCl}_{2}$, kat. DMF; b: $(S)$-leucin-metilészter-hidrogén-klorid, Et 3 N, THF; c: THF-AcOH-H $\mathrm{O}$ 8:1:1; $\Sigma=51 \%]$

az $(S, S)$-14 szenzormolekulához. Új fluoreszcens piridino-18-korona-6-éter-származékok előállítása érdekében a piridingyürü 4-es helyzetében lejátszódó szén-szén kapcsolási eljárásokat is kidolgoztunk. Az $(S, S)$-18 jódvegyület és 2-vinilbenzotiazol Heck-reakciójával nyertük az $(S, S)-15$ ligandumot. Az $(S, S)$-18 jódszármazék Suzuki-Miyaura keresztkapcsolási reakciójával előállítottuk az $(S, S)$-19 aldehidet, amelyet 2-aminotiofenollal reagáltatva jutottunk az (S,S)-16 ligandumhoz (4. ábra).<smiles></smiles>

$(S, S)-15$<smiles>C[C@H]1COCCOCCOC[C@H](C)OCC2=CC(I)=CC(=N1)CO2</smiles>

$(S, S)-18$<smiles></smiles>

$(S, S)-17$<smiles></smiles>

(S,S)-14<smiles>C[C@H]1COCCOCCOC[C@H](C)OCC2=CC(c3ccc(C=O)cc3)=CC(=N1)CO2</smiles>

(S,S)-19

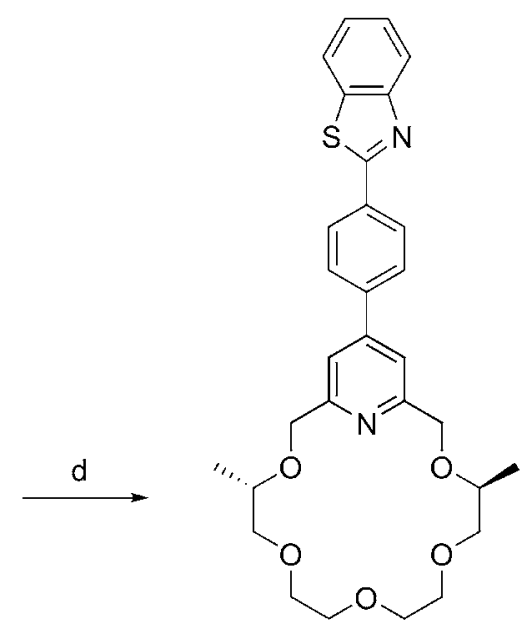

$(S, S)-16$

4. Ábra. Az (S,S)-14-(S,S)-16 új piridino-koronaéter-alapú szenzormolekulák szintézise [a: 2-klórbenzotiazol, NaH, THF, DMF, 18\%; b: 2-vinilbenzotiazol, $\mathrm{Pd}(\mathrm{OAc})_{2}, \mathrm{~K}_{2} \mathrm{CO}_{3}$, DMF, 44\%; c: 4-formilfenilboronsav, $\mathrm{Pd}\left(\mathrm{PPh}_{3}\right)_{4}, \mathrm{~K}_{3} \mathrm{PO}_{4}, \mathrm{KBr}$, dioxán- $\mathrm{H}_{2} \mathrm{O}$ 6:1, 40\%; d: 2-aminotiofenol, EtOH, 18\%]

126. évfolyam, 1. szám, 2020. 


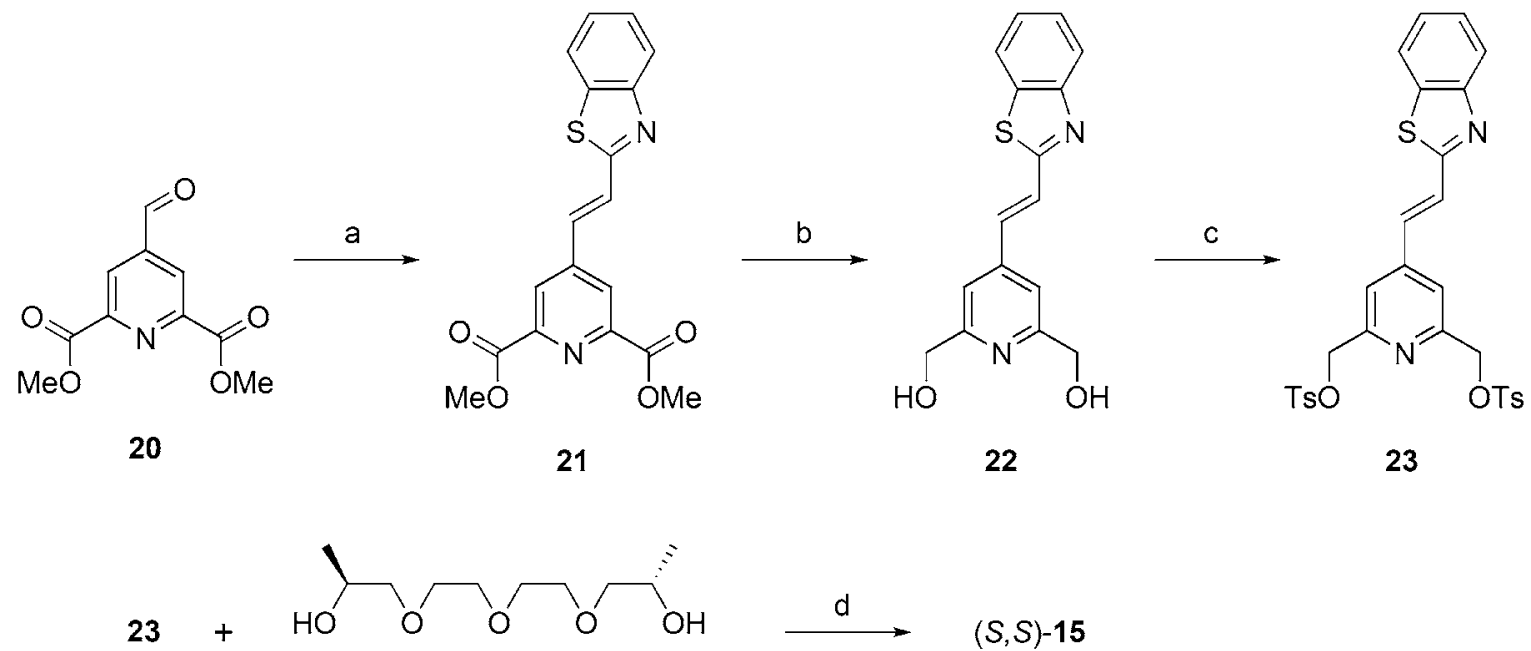

$(S, S)-24$

5. Ábra. Alternatív szintézisút az $(S, S)-15$ szenzormolekula előállítására (a: 2-metilbenzotiazol, $\mathrm{AcOH}_{2} \mathrm{Ac}_{2} \mathrm{O}, 65 \%$; b: $\mathrm{NaBH}_{4}, \mathrm{CaCl}_{2}, \mathrm{MeOH}, 82 \%$; c: TsCl, vizes $\mathrm{KOH}, \mathrm{CH}_{2} \mathrm{Cl}_{2}, 61 \%$; d: $\mathrm{NaH}, \mathrm{THF}, 6 \%$ )

A 20 formilpiridin-diészterből kiindulva egy másik szintézisutat is kidolgoztunk az $(S, S)$-15 piridino-koronaéter előállítására (5. ábra). A 20 formilszármazékot 2-metilbenzotiazollal ecetsav és ecetsav-anhidrid elegyében melegítve jutottunk a 21 vinilén egységet tartalmazó diészterhez. Az utóbbi vegyületet nátrium-tetrahidrido-boráttal kalcium-klorid jelenlétében metanol oldószerben reagáltatva szelektíven állítottuk elő a $\mathbf{2 2}$ diolt, amely tozilezésével a 23 ditoziláthoz jutottunk. A 23 ditozilátot és az enantiomertiszta dimetil-szubsztituált $(S, S)$-24 tetraetilénglikolt felhasználva Williamson-féle éterszintézissel állítottuk elő az $(S, S)$-15 szenzormolekulát.

Nyolc új, pirén fluoreszcens jelzőegységet tartalmazó azaés diazakoronaéter-alapú ligandumot $[(R, R)-\mathbf{2 5}-(R, R)-\mathbf{2 8}$ és $(S, S)-\mathbf{2 5}-(S, S)-\mathbf{2 8}, 6$. ábra] állítottunk elö. ${ }^{29}$

Pirén-1-ilmetánamin (29) és $(R)$-, vagy $(S)$-feniloxirán metanol oldószerben, bombacsőben történő melegítésével jutottunk az enantiomertiszta $(R, R)$-30 és $(S, S)$-30 aminodiolokhoz. Az aminodiolok és tetraetilénglikol-ditozilát makrociklizációs reakciójával nyertük az $(R, R)$-25 és $(S, S)$ 25 azakoronaétereket.

A bisz(2-metoxifenil)amint (31) metil-jodiddal alkilezve a $32 N$-metilezett amint kaptuk. A 33 difenol előállításához a 32 amin szelektív $O$-demetilezését vízmentes alumínium-kloriddal klórbenzolban végeztük. A 34 és 33 difenolszármazékok benzilcsoporttal védett etilénglikol-toziláttal (35) végbemenő reakciója rendre a 36 formamidszármazékot és a 37 tercier amint adta. A 36 és $37 O$-benzil-védett származékok katalitikus hidrogenolízisével állítottuk elő a 38 és 39 diolokat, amelyeket a 40 és 41 ditozilátokká alakítottunk. A 40 és 41 ditozilátokat oldószerként $N, N$ dimetilformamidot, bázisként nátrium-hidridet alkalmazva makrociklizációs reakcióba vittük az $(R, R)$-30 vagy $(S, S)$ -
30 aminodiolokkal. A 40 ditozilátból kiinduló reakciók deformileződés következtében az $(R, R)$-26 és $(S, S)$-26 makrociklusokat adták fötermékként. A 41 ditozilátból kiinduló reakciókból a várt $(R, R)$-28 és $(S, S)$-28 szenzormolekulákat nyertük. Az $(R, R)$-26 és $(S, S)$-26 ligandumokat hangyasav és ecetsav-anhidrid keverékével formilezve sikeresen elöállítottuk az $(R, R)-27$ és $(S, S)-27$ makrociklusokat (6. ábra).

Egy másik szintézisutat is kidolgoztunk az $(S, S)$-28 diazakoronaéter előállítására olyan új enantiomertiszta prekurzorokon (7. ábra) keresztül, amelyek más enantiomerszelektív fluoreszcens szenzormolekulák előállításában is hasznosíthatók. A $\mathbf{4 2}$ metoximetil (MOM)-csoporttal védett etilénglikolt a $\mathbf{4 3}$ toziláttá alakítottuk. Az így kapott alkilezőszer és az enantiomertiszta $(R, R)$-30 vagy $(S, S)$-30 $(6$. ábra) aminodiolok reakciójával állítottuk elő az $(R, R)-44$ és $(S, S)$-44 MOM-csoporttal védett származékokat. A védöcsoportokat vizes sósavval távolítottuk el. Az így kapott $(R, R)$-45 és $(S, S)$-45 diolokat az $(R, R)$-46 és $(S, S)$-46 ditozilátokká alakítottuk. A 33 difenolszármazék (6. ábra) $(S, S)$-46 ditoziláttal történő $O$-alkilezésével az $(S, S)-28$ makrociklushoz jutottunk.

\subsection{Szenzormolekulák vizsgálata}

Az $(S, S)$-6- $(S, S)$-11 és az $(S, S)-\mathbf{1 3}$ receptorok enantiomerfelismerő-képességét mandulasav, terc-butoxikarbonil-védett fenilglicin, terc-butoxikarbonil-védett fenilalanin és terc-butoxikarbonil-védett alanin tetrabutilammónium-sóinak (Man, Boc-Phg, Boc-Phe és Boc-Ala) enantiomerjeivel szemben acetonitrilben (ha másképp nem jelöltük) vizsgáltuk. $^{25-27}$ 
<smiles>NCc1ccc2ccc3cccc4ccc1c2c34</smiles>

29<smiles>OC(CN(Cc1ccc2ccc3cccc4ccc1c2c34)c1ccccc1)c1ccccc1</smiles>

$(R, R)-30$ vagy $(S, S)-30$

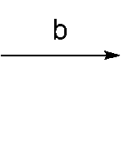

$(R, R)-25$ vagy $(S, S)-25$

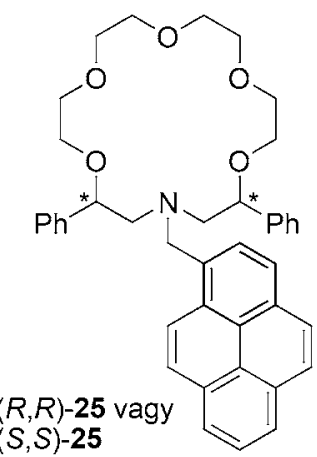<smiles>COc1ccccc1Nc1ccccc1OC</smiles><smiles>C=C</smiles><smiles>COc1ccccc1N(C)c1ccccc1OC</smiles><smiles>C=C</smiles><smiles>CN(c1ccccc1O)c1ccccc1O</smiles>

32

33

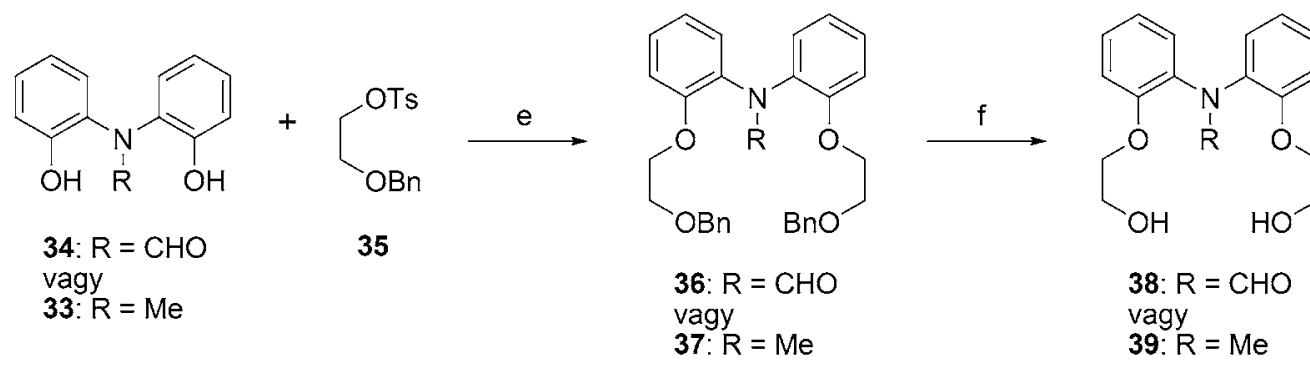

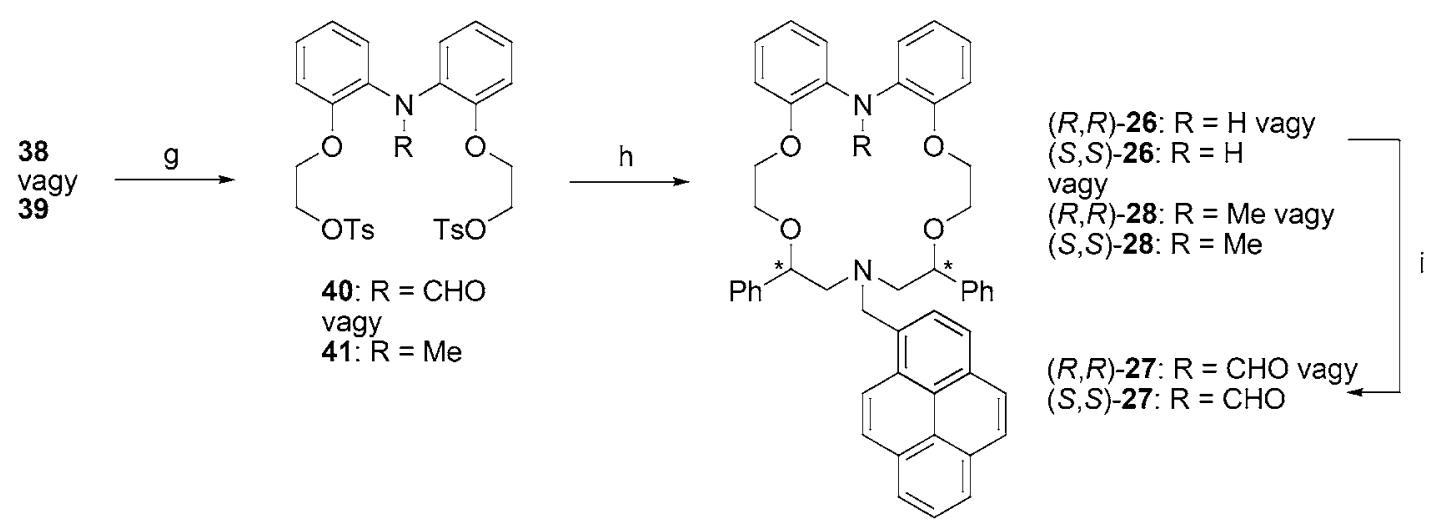

6. Ábra. A pirén egységet tartalmazó új koronaéterek szintézise [a: $(R)$-feniloxirán vagy $(S)$-feniloxirán, $\mathrm{MeOH}, 57 \%, 49 \%$; b: tetraetilénglikol-ditozilát, $\mathrm{NaH}$, THF, 33\%, 26\%; c: MeI, NaH, THF, 95\%; d: AlCl , klórbenzol, 76\%; e: $\mathrm{K}_{2} \mathrm{CO}_{3}$, MeCN, 77\%, 78\%; f: $\mathrm{H}_{2}, \mathrm{Pd} / \mathrm{C}, \mathrm{MeOH}, 98 \%, 100 \%$; g: TsCl, $\mathrm{CH}_{2} \mathrm{Cl}$, $\mathrm{R}=\mathrm{CHO}: \mathrm{Et}_{3} \mathrm{~N}, 91 \%, \mathrm{R}=\mathrm{Me}$ : vizes $\mathrm{KOH}, 94 \%$; h: $(R, R)-\mathbf{3 0}$ vagy $(S, S)-\mathbf{3 0}$, NaH, DMF, 29-35\%; i: $\left.\mathrm{HCOOH}, \mathrm{Ac}_{2} \mathrm{O}, i \operatorname{Pr}_{2} \mathrm{O}, 85 \%, 76 \%\right]$

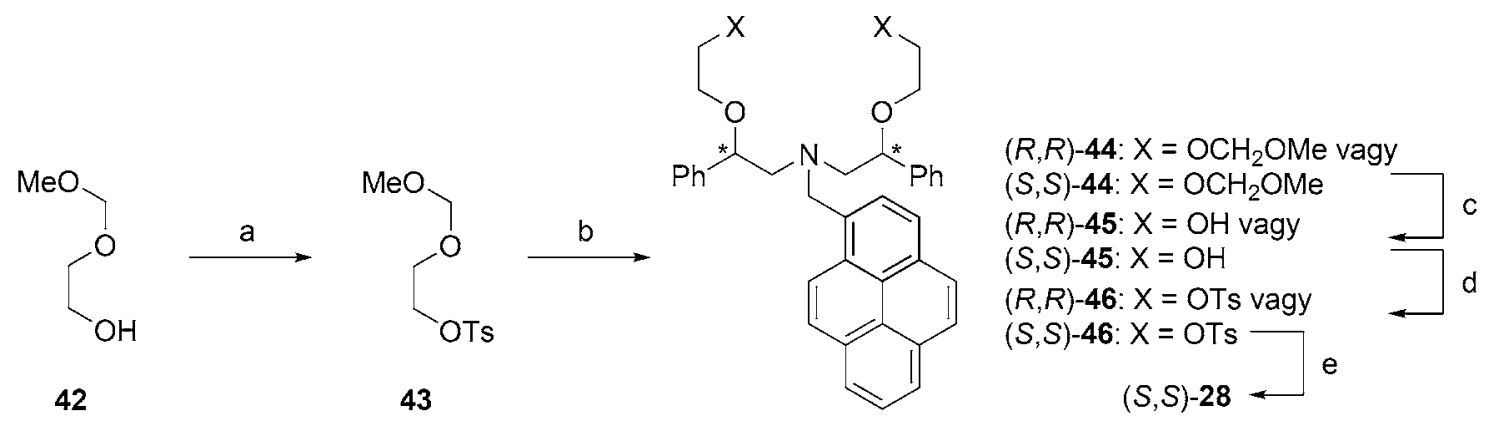

7. Ábra. Új prekurzorok szintézise [a: TsCl, vizes $\mathrm{KOH}, \mathrm{CH}_{2} \mathrm{Cl}$, $91 \%$; b: $(R, R)$-30 vagy $(S, S)-30, \mathrm{NaH}, \mathrm{THF}, \mathrm{DMF}, 67 \%, 70 \%$; c: vizes $\mathrm{HCl}, \mathrm{THF}, 98 \%$; d: TsCl, vizes $\mathrm{KOH}, \mathrm{CH}_{2} \mathrm{Cl}_{2}, 43 \%, 52 \%$; e: 33, $\left.\mathrm{K}_{2} \mathrm{CO}_{3}, \mathrm{MeCN}, 20 \%\right]$

126. évfolyam, 1. szám, 2020. 
Az $(S, S)$-6 és $(S, S)$-7 szenzormolekulák esetében a vizsgált karboxilátok hozzáadására a fluoreszcencia emisszió csökkenését figyeltük meg a titrálási spektrumsorozatokban (acetonitril-DMSO 99:1 elegyben), amelyeket 1:1 sztöchiometriájú komplexek kialakulását feltételezve megfelelően lehetett illeszteni. Az eredmények alapján az $(S, S)$-6 receptormolekula jelentős enantiomerfelismerést mutatott az $(S)$-Boc-Ala esetében az $(R)$-izomerrel szemben $(\Delta \lg K$ $=-0,56)$ (8. ábra). Ugyanakkor az $(S, S)-6$ bisz(karbamid) gyakorlatilag nem mutatott felismerőképességet az aszimmetriacentrumaikon fenil-, illetve benzilcsoportot tartalmazó karboxilát (Man, Boc-Phg és Boc-Phe) enantiomerekkel szemben. Ez magyarázható azzal, hogy a karboxilát- és az NH-csoportok hidrogénkötéses kölcsönhatása mellett további $\pi-\pi$ kölcsönhatás lép fel az egyik karbamid egység karbonilcsoportja és a fenil-, illetve benzilcsoport között. Emellett feltételezhető, hogy az alifás, kisebb térkitöltésü metilcsoportot tartalmazó Boc-Ala enantiomerek komplexei a Man, Boc-Phg és Boc-Phe vendégmolekulák komplexeihez képest eltérő szerkezettel rendelkeznek. A karbamid és tiokarbamid kötőhelyek különbözősége kiemelkedő hatással volt az enantiomerszelektivitásra, nevezetesen az $(S, S)-7$ receptor közepes szelektivitást mutatott a legtöbb vizsgált anion enantiomerjeivel szemben (az egyetlen kivétel a Boc-Phe volt). ${ }^{25}$
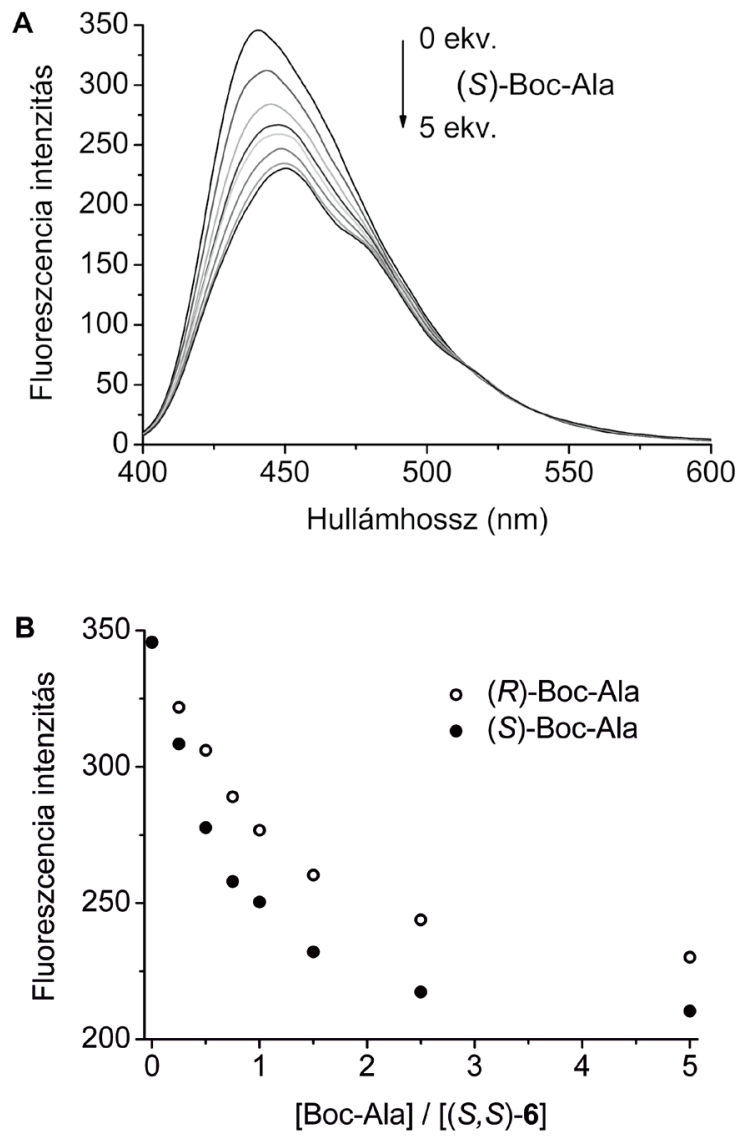

8. Ábra. Az $(S, S)$-6 anionszenzor $(2 \mu \mathrm{M})(S)$-Boc-alanináttal $(0,0,25$, $0,5,0,75,1,1,5,2,5,5$ ekv.) történő titrálása során kapott spektrumsorozat 1\% dimetil-szulfoxidot tartalmazó acetonitrilben (A). Titrálási görbék $(R)$-Boc-Ala és $(S)$-Boc-Ala (0-5 ekv.) esetén 440 nm-en (B)
Míg az $(S, S)$-10 bisz(karbamid) esetében emisszió növekedést, addig az $(S, S)$-11 bisz(tiokarbamid) esetében emiszszió csökkenést tapasztaltunk a karboxilátokkal történő titrálások során, amelyeket 1:1 sztöchiometriájú komplexek kialakulását feltételezve megfelelően lehetett illeszteni. A legtöbb esetben az $(S, S)$-10 és $(S, S)$-11 szenzormolekulák nem, vagy csak kismértékü enantiomerszelektivitást mutattak a királis karboxilátok enantiomerjeivel szemben. A legnagyobb mértékü, de csak közepes felismeröképességet az $(S, S)$-11 és a Boc-Phg enantiomerjei esetében figyeltük meg $(\Delta \lg K=0,24)$. Az $(S, S)$-8 és $(S, S)$-9 receptormolekulák esetében a királis karboxilátok jelenlétében bekövetkező kisebb mértékü abszorpciós és emissziós spektrális változások nem tették lehetővé a komplexstabilitási állandók pontos meghatározását. ${ }^{26}$

Röntgenkrisztallográfiai módszerrel meghatároztuk az $(S, S)$-13 akridonszármazék kristályszerkezetét. A 9. A ábrán látható, hogy az akridon NH-csoportja és az amid egységek O-atomjai között intramolekuláris bifurkált hidrogénkötés alakul ki. Az $(S, S)$-13 receptor izobutil- és metoxikarbonil-csoportjai mozgékonyságot mutattak a kristályban (9.A ábra). ${ }^{27}$

Az $(S, S)$-13 molekula emissziós spektrumában két sáv látható: az egyik 427 nm-nél, amely a változatlan szenzormolekulától ered, és egy másik, jelentősen kisebb intenzitású, szélesebb sáv 586 nm-nél (9.B ábra), amely valószínüleg az akridon NH-csoportról az amid O-atomok felé irányuló gerjesztett állapotú intramolekuláris protonátadás (ESIPT) ${ }^{30}$ révén alakul ki. A folyamatot elősegíti az alapállapotban jelenlévő, az akridon NH-csoportja és az amid O-atomok közötti hidrogénkötés (9.A ábra).

Az $(S, S)$-13 receptor oldatában egyik királis karboxilát sem okozott komplexképzésre jellemző spektrális változást. A Boc-Ala és Boc-Phe enantiomerek adagolása kis mennyiségü deprotonált receptormolekula kialakulásához vezetett (9.B ábra).

Az $(S, S)$-13 szenzormolekula felismerőképességét akirális anionokkal $\left(\mathrm{F}^{-}, \mathrm{Cl}^{-}, \mathrm{Br}^{-}, \mathrm{I}^{-}, \mathrm{NO}_{3}^{-}, \mathrm{ClO}_{4}^{-}, \mathrm{HSO}_{4}^{-}, \mathrm{H}_{2} \mathrm{PO}_{4}^{-}\right.$és $\mathrm{AcO}^{-}$tetrabutilammónium-sókkal) szemben is vizsgáltuk acetonitrilben. Az UV-látható és fluoreszcenciás spektrális változások komplexképzés hiányára utaltak, a $\mathrm{F}^{-}-, \mathrm{AcO}^{-}-$ és $\mathrm{H}_{2} \mathrm{PO}_{4}^{-}$-ionok pedig deprotonálták a szenzormolekulát, amely az abszorpciós és emissziós spektrumok jelentős batokróm eltolódásával járt. A vizsgált anionok közül a $\mathrm{F}^{-}$ion hatása kiemelkedő (9.B és 10.A ábra), így 4 ekv. anion jelenlétében $\mathrm{F}^{-}$-ionra szelektív abszorpciós és fluoreszcenciás választ figyelhettünk meg. A $\mathrm{F}^{-}$-ion 1:2 szenzormolekula-anion sztöchiometriájú deprotonálódást okozott a stabil $\left[\mathrm{HF}_{2}\right]^{-}$-ion képződése révén, míg az $\mathrm{AcO}^{-}$- és $\mathrm{H}_{2} \mathrm{PO}_{4}^{-}{ }^{-}$ ionok esetében 1:1 sztöchiometriájú sav-bázis egyensúlyt tapasztaltunk. ${ }^{27}$

Az észter- és amidcsoportok karbonil O-atomjának fémionkoordináló-képessége miatt acetonitrilben tanulmányoz- 
A
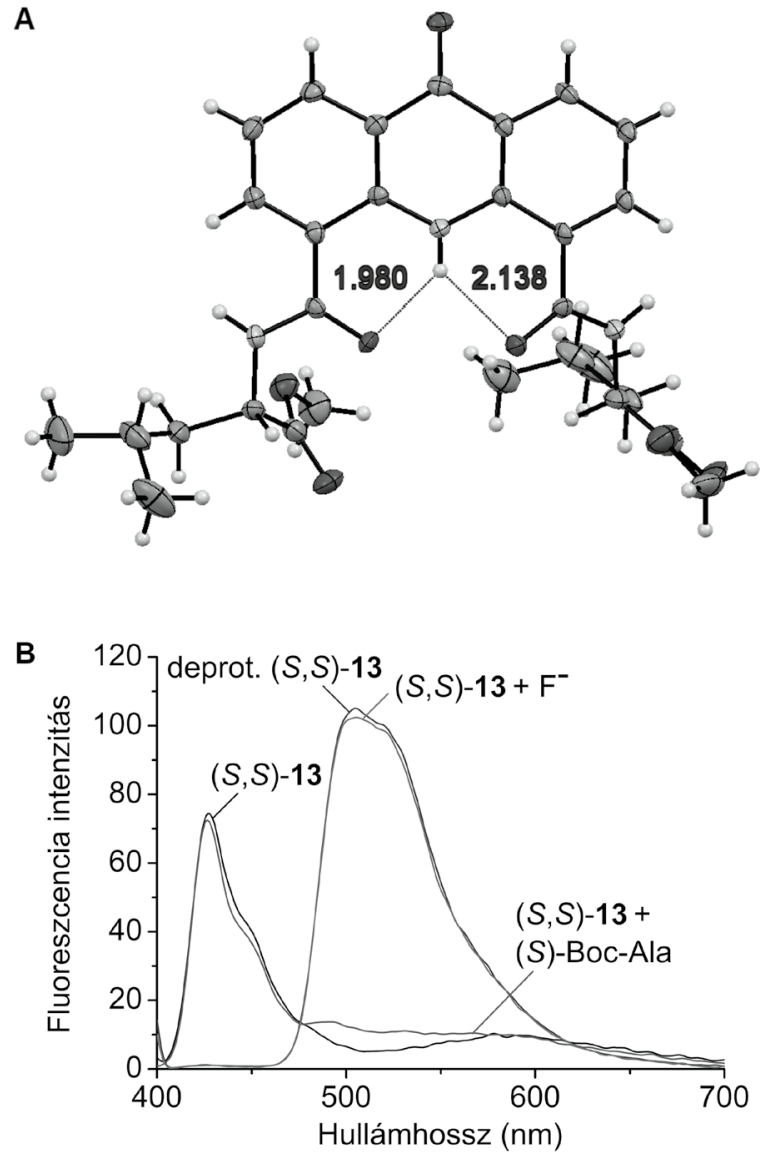

9. Ábra. Az $(S, S)$-13 szenzormolekula szerkezete ORTEP diagramon ábrázolva, az intramolekuláris bifurkált hidrogénkötést számozott vonalakkal jelöltük, a távolságokat Å-ben adtuk meg (A). Az (S,S)-13 szenzormolekula $(20 \mu \mathrm{M})$ fluoreszcencia spektruma és a spektrumok 50 ekv. DBU (deprotonált forma), 4 ekv. F-, illetve 200 ekv. (S)-Boc-Ala jelenlétében acetonitrilben (B)

tuk az $(S, S)$-13 szenzormolekula fémionokkal $\left(\mathrm{Li}^{+}, \mathrm{Na}^{+}, \mathrm{K}^{+}\right.$, $\mathrm{Mg}^{2+}, \mathrm{Ca}^{2+}, \mathrm{Zn}^{2+}, \mathrm{Cu}^{2+}, \mathrm{Ni}^{2+}, \mathrm{Ag}^{+}, \mathrm{Cd}^{2+}, \mathrm{Hg}^{2+}$ és $\mathrm{Pb}^{2+}$ perklorát-sóival) szemben mutatott komplexképzését is. $\mathrm{Hg}^{2+}$-ion hozzáadásakor arra szelektíven jelentős batokróm eltolódást figyeltünk meg az UV-látható spektrumban, amely annak tulajdonítható, hogy az akridon egység 9-hidroxiakridin tautomer formába alakul a komplexképződéskor. Míg a $\mathrm{Ca}^{2+}$-ion enyhe, addig a $\mathrm{Hg}^{2+}$-ion jelentős batokróm eltolódással indukált nagy fluoreszcencia-erösítést (10.B ábra). Az emissziós jelváltozás $425 \mathrm{~nm}$-en $\mathrm{Ca}^{2+}$-ionra, míg 550 nm-en $\mathrm{Hg}^{2+}$-ionra mutatott szelektivitást. A titrálási spektrumsorozatokat 1:1 sztöchiometriájú komplexek kialakulását feltételezve megfelelöen lehetett illeszteni, azonban nagy $\mathrm{Ca}^{2+}$-ion felesleg esetén 1:2 receptor-fémion sztöchiometriájú komplex képződését figyeltük meg. ${ }^{27}$

Az $(S, S)$-13 szenzormolekula anionokkal és kationokkal szemben tapasztalt optikai válaszait felhasználva két bemenettel és egy kimenettel rendelkező logikai kapukat hoztunk létre. $\mathrm{A} \mathrm{F}^{-}$- és $\mathrm{Ca}^{2+}$-ionokat kémiai bemenetekként alkalmaztuk, és kihasználtuk az ionok reakcióját. A logikai müveletekhez bemenetként rendre $80 \mathrm{ekv}$. $\mathrm{F}^{-}$-iont, illetve $40 \mathrm{ekv}$. $\mathrm{Ca}^{2+}$-iont alkalmaztunk, a kimeneteket pedig a 425, 550 és $483 \mathrm{~nm}$-en mért fluoreszcencia intenzitások,
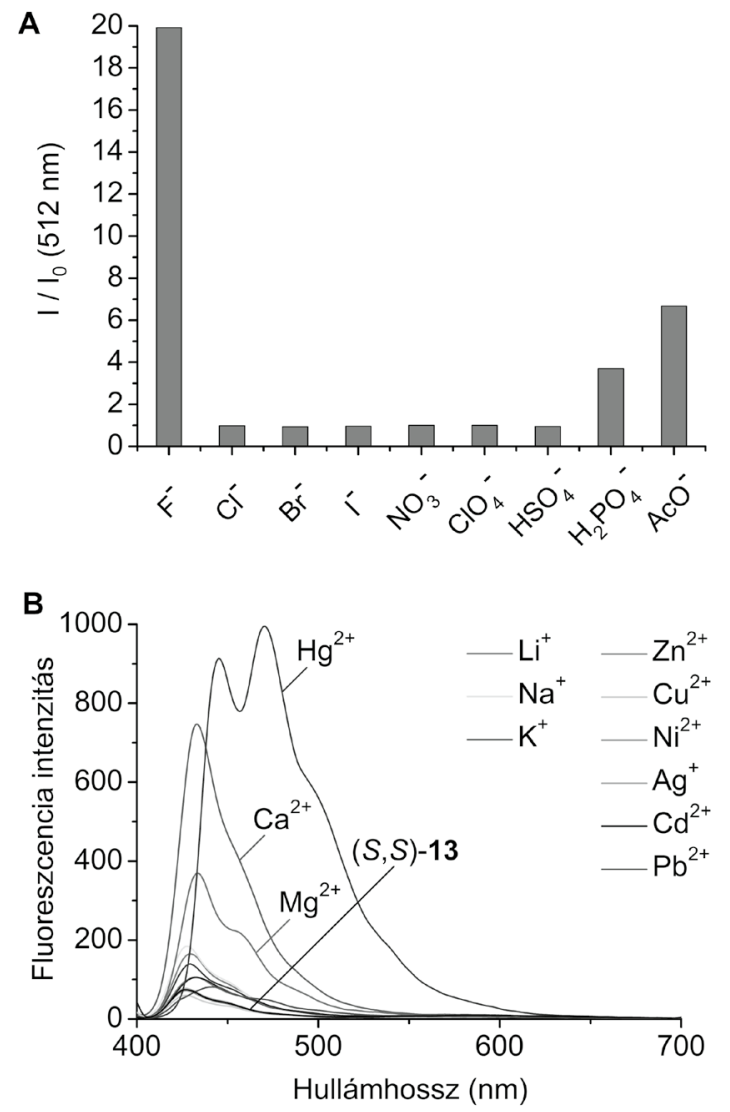

10. Ábra. Az $(S, S)-13$ szenzormolekula $(20 \mu \mathrm{M})$ fluoreszcencia-erősítése 512 nm-en 4 ekv. anion jelenlétében acetonitrilben (A). Az $(S, S)$-13 szenzormolekula $(20 \mu \mathrm{M})$ fluoreszcencia spektruma, valamint a spektrumok 400 ekv. kation jelenlétében acetonitrilben (B)

illetve a 310 és $475 \mathrm{~nm}$-en mért abszorbanciák relatív értéke adta, így IMP, INH, XOR és XNOR logikai kapukhoz jutottunk. Bizonyos molekuláris logikai kapuk kombinációjával komplementer IMP/INH, félkivonó (XOR/INH) és összehasonlító (XNOR/INH) logikai hálózatokat nyertünk, amelyek egyetlen molekulával és bemeneti halmazzal müködtethetők. A kimenetek egyikén negatív logikai módot alkalmazva mindhárom összetett logikai müvelet végrehajtható fluoreszcencia spektroszkópia alkalmazásával. ${ }^{27}$

Az $(S, S)$-14- $(S, S)$-16, $(S, S)$-25- $(S, S)$-28 és $(R, R)$-25- $(R, R)$ 28 koronaéterek felismerőképességét 1-feniletil-amin-, 1-(naftalin-1-il)etil-amin-, fenilglicin-metilészter- és fenilalanin-metilészter-hidrogén-perklorátok (PhEt, NapEt, PhgOMe és PheOMe) enantiomerjeivel szemben acetonitrilben vizsgáltuk. ${ }^{28,29}$

Az $(S, S)$-14- $(S, S)$-16 makrociklusok oldatához PhEt és NapEt enantiomereket adva jelentős fluoreszcencia-kioltást tapasztaltunk. Az $(S, S)$-16 ligandum PhgOMe és PheOMe sókkal történő titrálásakor a szabad receptormolekula emissziós sávjának kioltása mellett azonban egy új emissziós sáv is megjelent (11.A ábra). Az utóbbi spektrumalak az $(S, S)$-16 ligandum protonált formájának kialakulására utal. 
Az abszorpciós titrálás spektrumsorozata az alapállapotú komplexképzés mellett elhanyagolható mértékü protonálódást mutatott, tehát az $(S, S)$-16 ligandum protonálódása csak gerjesztett állapotban történt meg. Feltételezhetö, hogy a protonált ligandum a hidrogénkötéssel összetartott komplexből alakult ki, mert a fluoreszcenciás titrálások spektrumsorozatait 1:1 sztöchiometriájú komplexképződést feltételezve jól lehetett illeszteni. A komplex gerjesztésével bekövetkező protonátmenet jelenségét az $(S, S)-\mathbf{1 5}$ koronaéter és a PhgOMe, illetve a PheOMe sók esetében szintén tapasztaltuk. A szenzormolekulák közepes, illetve jelentős enantiomerfelismerő-képességet mutattak a PhEt, NapEt és PhgOMe enantiomerekkel szemben. A legnagyobb mértékü enantiomerfelismerést az $(S, S)$-15 és $(S, S)$-16 piridino-koronaéterek esetében, PhEt és NapEt sókkal szemben figyeltük meg ( $\Delta \lg K 0,28$ és 0,35 között). ${ }^{28}$
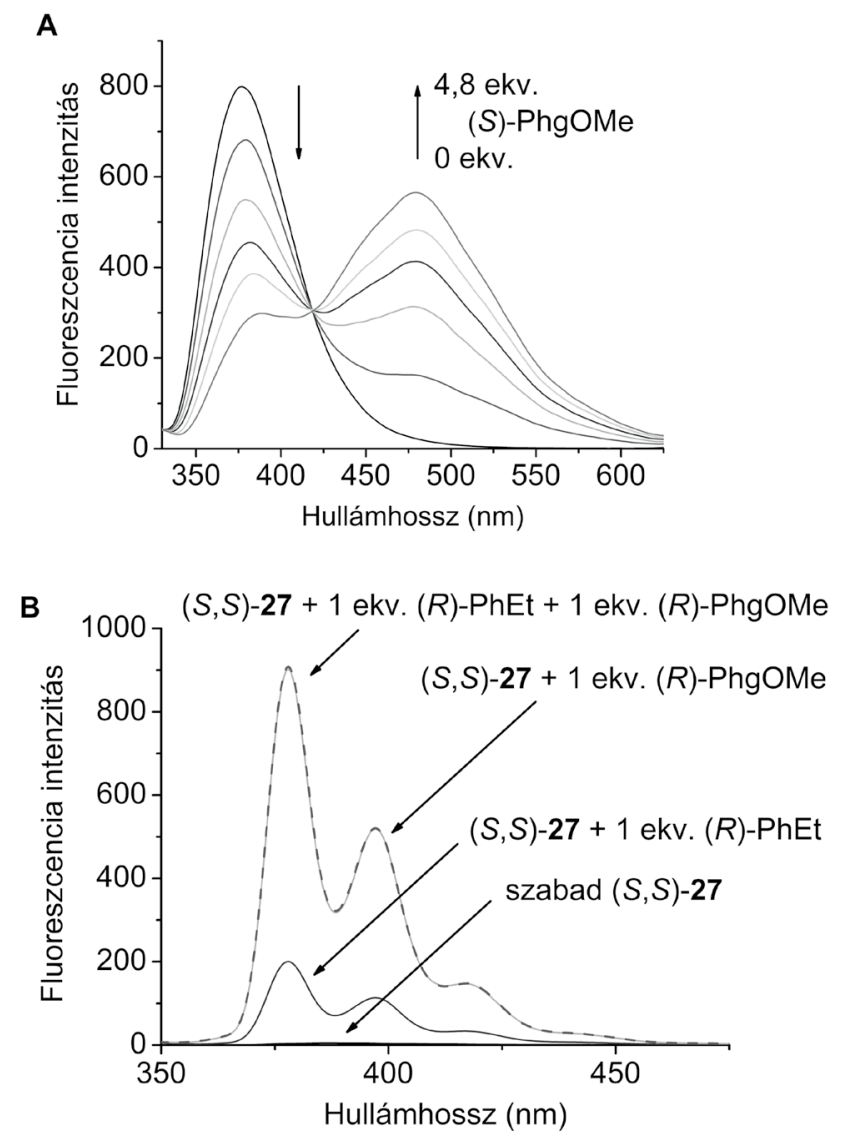

11. Ábra. Az $(S, S)$-16 ligandum $(5 \mu \mathrm{M})(S)$-PhgOMe sóval $(0,0,4,0,8$, 1,4, 2,4, 4,8 ekv.) történő titrálása során kapott fluoreszcencia spektrumsorozat acetonitrilben (A). Az $(S, S)-27$ ligandum $(20 \mu \mathrm{M})$ spektruma és a spektrumok 1 ekv. $(R)$-PhEt, 1 ekv. $(R)$-PhgOMe, valamint 1 ekv. $(R)$-PhEt +1 ekv. $(R)$-PhgOMe jelenlétében acetonitrilben $(\mathbf{B})$

Az $(R, R)$-25- $(R, R)$-28 és $(S, S)$-25- $(S, S)$-28 szenzormolekulák PhEt, NapEt, PhgOMe és PheOMe enantiomerekkel történő fluoreszcenciás titrálása során kiemelkedő mértékü intenzitásnövekedést tapasztaltunk (11.B ábra). A protonált primer amin enantiomerek komplexálása minden esetben a (trialkil-amin típusú) N-atomtól a pirén egység felé irányuló PET típusú kioltási folyamat gátlását okozta, amely a pirén egység emissziós sávjainak (378, 397 és 417 nm) meg- jelenését eredményezte. A titrálási spektrumsorozatokat 1:1 sztöchiometriájú komplexek kialakulását feltételezve jól lehetett illeszteni. A szenzormolekulák gyakorlatilag nem mutattak enantiomerfelismerö-képességet, azonban egyfajta molekuláris felismerést tapasztaltunk. Megfigyeltük, hogy a PhgOMe és PheOMe komplexei sokkal stabilabbak a PhEt és NapEt komplexeinél. Az $(R, R)$-27 és $(S, S)$-27 diazakoronaéterek jelentősen stabilabb komplexeket képeztek a protonált aminosav-észterekkel (PhgOMe és PheOMe, lg $K$ 6,25 és 6,51 között), mint a protonált primer aminokkal (PhEt és NapEt, $\lg K$ 3,79 és 4,09 között), amely alkalmassá teszi ezen makrociklusokat protonált aminosav-észterek szelektív felismerésére (11.B ábra). ${ }^{29}$

\section{Kísérleti rész}

A szintetikus munka során preparatív szerves kémiai módszereket alkalmaztunk. A reakciók előrehaladását és a termékek tisztaságát vékonyréteg kromatográfiásan ellenőriztük. A nyerstermékek tisztítását átkristályosítással, légköri, illetve csökkentett nyomáson történő desztillációval, oszlop- vagy rétegkromatográfiás módszerekkel, valamint megfelelő oldószerrel történő eldörzsöléssel végeztük. Az új vegyületeket fizikai állandóikkal (olvadáspont, optikai forgatóképesség), spektroszkópiai adatokkal (IR, ${ }^{1} \mathrm{H}$ NMR, ${ }^{13} \mathrm{C}$ NMR, MS) és elemi analízissel jellemeztük. Az $(S, S)$-13 vegyület kristályszerkezetének meghatározását röntgendiffrakciós méréssel $109 \mathrm{~K}$-en, Dr. Vértessy G. Beáta és Leveles Ibolya végezte. ${ }^{26}$

Az új receptormolekulák komplexképzési tulajdonságait optikailag aktív sók enantiomerjeivel, valamint különböző anionokkal és fémionokkal szemben UV-látható és fluoreszcencia spektroszkópiával tanulmányoztuk. A komplexstabilitási állandókat a fluoreszcenciás titrálások alapján a globális nemlineáris regressziót alkalmazó SPECFIT/32 $2^{\mathrm{TM}}$ program segítségével Dr. Baranyai Péter határozta meg. ${ }^{24-}$ ${ }^{28} \mathrm{Az}$ enantiomerszelektivitás kifejezésére a $\Delta \lg K=\lg K_{(\mathrm{R})}$ - $\lg K_{(\mathrm{S})}$ számítást alkalmaztuk.

\section{4. Összefoglalás}

Sikeresen szintetizáltunk enantiomertiszta fluoreszcens anionreceptorokat, koronaétereket, valamint ezek prekurzorait.

Az $(S, S)$-6 és $(S, S)$-10 bisz(karbamid), valamint az $(S, S)$ 7 és $(S, S)$-11 bisz(tiokarbamid) típusú vegyületek alkalmas anionszenzoroknak bizonyultak biológiailag fontos deprotonált karbonsav-származékok enantiomerjeivel szemben. A karbamid és tiokarbamid egységek különbözősége kiemelkedő hatással van az enantiomerszelektivitás mértékére.

Az $(S, S)$-13 akridon, valamint amid és észter egységeket egyaránt tartalmazó szenzormolekula szelektivitást mutatott $\mathrm{F}^{-}$-, $\mathrm{Ca}^{2+}$ - és $\mathrm{Hg}^{2+}$-ionokkal szemben. A vegyület $\mathrm{F}^{-}$- és $\mathrm{Ca}^{2+}$-ionok jelenlétére adott optikai válaszjelét alkalmazva 
két kémiai bemenettel és egy optikai kimenettel rendelkező molekuláris logikai kapukat határoztunk meg.

Az $(S, S)$-14-(S,S)-16 benzotiazol fluorofort tartalmazó piridino-18-korona-6-éter-alapú szenzormolekulák közepes vagy jelentős mértékű enantiomerfelismerését tapasztaltuk protonált primer aminok enantiomerjeivel szemben.

A pirén fluorofort tartalmazó aza- és diaza-18-korona-6-éterek $\quad[(R, R)-\mathbf{2 5}-(R, R)-\mathbf{2 8} \quad$ és $\quad(S, S)-\mathbf{2 5}-(S, S)-\mathbf{2 8}]$ protonált primer aminokkal és aminosav-észterekkel való komplexképzéséről a fényindukált elektronátadás (PET) gátlásának következtében a fluoreszcencia intenzitás kiemelkedően nagy növekedése adott jelet. Megállapítottuk, hogy az $N$-formilcsoportot tartalmazó diazakoronaéter jelentősen stabilabb komplexeket képez a vizsgált protonált aminosav-észterekkel, mint a protonált primer aminokkal.

\section{Köszönetnyilvánítás}

A szerzők köszönik a Nemzeti Kutatási, Fejlesztési és Innovációs Hivatal (K112289, K128473 és PD104618), az Új Nemzeti Kiválóság Program (ÚNKP-16-3-I.) és az Új Széchenyi Terv TÁMOP-4.2.1/B-09/1/KMR-2010-0002 program anyagi támogatását.

\section{Hivatkozások}

1. Fischer, E. Ber. Dtsch. Chem. Ges. 1894, 27, 2985-2993. https://doi.org/10.1002/cber.18940270364

2. Pirkle, W. H.; Pochapsky, T. C. Chem. Rev. 1989, 89, 347-362. https://doi.org/10.1021/cr00092a006

3. Atwood, J. L.; Steed, J. W. Encyclopedia of Supramolecular Chemistry, Marcel Dekker: New York, NY, 2004.

4. Pedersen, C. J. J. Am. Chem. Soc. 1967, 89, 2495-2496.; ugyanott 7017-7036. https://doi.org/10.1021/ja00986a052; https://doi.org/10.1021/ja01002a035

5. Hamann, B. C.; Branda, N. R.; Rebek, J., Jr. Tetrahedron Lett. 1993, 34, 6837-6840. https://doi.org/10.1039/b404706k

6. Gunnlaugsson, T.; Davis, A. P.; Hussey, G. M.; Tierney, J.; Glynn, M. Org. Biomol. Chem. 2004, 2, 1856-1863. https://doi.org/10.1039/b404706k

7. Griesbeck, A. G.; Hanft, S.; Miara, Y. D. Photochem. Photobiol. Sci. 2010, 9, 1385-1390. https://doi.org/10.1039/c0pp00175a

8. Trejo-Huizar, K. E.; Ortiz-Rico, R.; Peña-González, M. A.; Hernández-Rodríguez, M. New J. Chem. 2013, 37, 2610-2613. https://doi.org/10.1039/c3nj00644a

9. Zhou, X.-B.; Yip, Y.-W.; Chan, W.-H.; Lee, A. W. M. Beilstein J. Org. Chem. 2011, 7, 75-81. https://doi.org/10.3762/ bjoc.7.11

10. Zhang, X.; Yin, J.; Yoon, J. Chem. Rev. 2014, 114, 4918-4959. https://doi.org/10.1021/cr400568b
11. Kormos, A.; Móczár, I.; Pál, D.; Baranyai, P.; Kupai, J.; Tóth, K.; Huszthy, P. Tetrahedron: Asymmetry 2013, 24, 62-65. https://doi.org/10.1016/j.tetasy.2012.11.020

12. Kyba, E. B.; Koga, K.; Sousa, L. R.; Siegel, M. G.; Cram, D. J. J. Am. Chem. Soc. 1973, 95, 2692-2693. https://doi.org/10.1021/ja00789a051

13. Zhang, X. X.; Bradshaw, J. S.; Izatt, R. M. Chem. Rev. 1997, 97, 3313-3361. https://doi.org/10.1021/cr960144p

14. You, L.; Zha, D.; Anslyn, E. V. Chem. Rev. 2015, 115, 7840 7892. https://doi.org/10.1021/cr5005524

15. de Silva, A. P.; Gunaratne, H. Q. N.; Gunnlaugsson, T.; Huxley, A. J. M.; McCoy, C. P.; Rademacher, J. T.; Rice, T. E. Chem. Rev. 1997, 97, 1515-1566. https://doi.org/10.1021/cr960386p

16. Valeur, B.; Leray, I. Coord. Chem. Rev. 2000, 205, 3-40. https://doi.org/10.1016/S0010-8545(00)00246-0

17. Callan, J. F.; de Silva, A. P.; Magri, D. C. Tetrahedron 2005 , $61,8551-8588$. https://doi.org/10.1016/j.tet.2005.05.043

18. Jeong, Y.; Yoon, J. Inorg. Chim. Acta 2012, 381, 2-14. https://doi.org/10.1016/j.ica.2011.09.011

19. Formica, M.; Fusi, V.; Giorgi, L.; Micheloni, M. Coord. Chem. Rev. 2012, 256, 170-192. https://doi.org/10.1016/j.ccr.2011.09.010

20. Wong, J. K.-H.; Todd, M. H.; Rutledge, P. J. Molecules 2017, $22,200$. https://doi.org/10.3390/molecules22020200

21. Wu, D.; Sedgwick, A. C.; Gunnlaugsson, T.; Akkaya, E. U.; Yoon, J.; James, T. D. Chem. Soc. Rev. 2017, 46, 7105-7123. https://doi.org/10.1039/C7CS00240H

22. Chowdhury, S.; Rooj, B.; Dutta, A.; Mandal, U. J. Fluoresc. 2018, 28, 999-1021. https://doi.org/10.1007/s10895-018-2263-y

23. Thapa, P.; Arnquist, I.; Byrnes, N.; Denisenko, A. A.; Foss, F. W., Jr.; Jones, B. J. P.; McDonald, A. D.; Nygren, D. R.; Woodruff, K. Sci. Rep. 2019, 9, 15097. https://doi.org/10.1038/s41598-019-49283-x

24. Madhuprasad; Bhat, M. P.; Jung, H.-Y.; Losic, D.; Kurkuri, M. D. Chem. Eur. J. 2016, 22, 6148-6178. https://doi.org/10.1002/chem.201504396

25. Pál, D.; Móczár, I.; Kormos, A.; Baranyai, P.; Óvári, L.; Huszthy, P. Tetrahedron: Asymmetry 2015, 26, 1335-1340. https://doi.org/10.1016/j.tetasy.2015.10.004

26. Pál, D.; Móczár, I.; Kormos, A.; Baranyai, P.; Huszthy, P. Tetrahedron: Asymmetry 2016, 27, 918-922. https://doi.org/10.1016/j.tetasy.2016.08.002

27. Pál, D.; Baranyai, P.; Leveles, I.; G. Vértessy, B.; Huszthy, P.; Móczár, I. ChemistrySelect 2019, 4, 11936-11943. https://doi.org/10.1002/slct.201903483

28. Pál, D.; Móczár, I.; Szemenyei, B.; Marczona, D.; Kocsis, I.; Prikler, G.; Vezse, P.; Baranyai, P.; Huszthy, P. Tetrahedron 2019, 75, 2900-2909. https://doi.org/10.1016/j.tet.2019.04.024

29. Pál, D.; Gede, M.; Móczár, I.; Baranyai, P.; Bagi, P.; Huszthy, P. Period. Polytech. Chem. Eng. 2020, 64, 20-36. https://doi.org/10.3311/PPch.14467

30. Chen, C.-L.; Chen, Y.-T.; Demchenko, A. P.; Chou, P.-T. Nat. Rev. Chem. 2018, 2, 131-143. https://doi.org/10.1038/s41570-018-0020-z 


\section{Synthesis and Studies of Enantiopure Fluorescent Sensor Molecules}

Living organisms are continuously exposed to numerous kinds of molecules and ions, which can have different physiological effects on them. Receptors in living organisms selectively bind some of these species like carboxylates, organic cations as well as various inorganic anions and metal ions by the action of a phenomenon called molecular recognition.

Enantiomeric recognition, which is a special case of molecular recognition, is also an omnipresent and vital phenomenon in Nature since a significant proportion of biologically active molecules contains at least one chiral center. Examples of its action include the anabolism and catabolism of single enantiomeric forms of amino acids and sugars. Chiral carboxylic acids, primary amines, amino acids and their derivatives are fundamental molecules of biological relevance. The determination of the enantiomeric composition and the separation of the single enantiomeric forms of chiral organic compounds are highly important tasks in pharmaceutical, pesticide, food and perfume industries, because one enantiomer of a biologically active chiral compound may have different physiological effects.

Fluorescence spectroscopy offers a selective and sensitive detection method with quick response time. Thus, the development of fluorescent chemosensors capable of recognizing molecules, ions or enantiomers selectively has gained much research interest. ${ }^{10,14}$ Controllable characteristics of an optical phenomenon such as fluorescence can serve as a basis for designing not only sensor molecules, but also molecular logic gates usable for constructing molecular devices having potential for information processing. ${ }^{15}$

Our work was focused on the synthesis and studies of enantiopure fluorescent sensor molecules having potential enantiomeric recognition ability or selective ion sensing properties, which may be suitable for constructing optical sensors. Acridone, 5,5-dioxophenothiazine, benzothiazole and pyrene fluorophores were used as fluorescent signaling units of these sensor molecules. The enantiomeric differentiation of deprotonated carboxylic acids and protonated primary amines and amino acid esters are advantageous, because these molecules exist in their ionic forms under physiological conditions. Therefore, we wished to investigate the complexation properties of the synthesized unreported sensor molecules toward these kinds of chiral ionic guests and in one case, toward metal ions and achiral anions as well.

Acridone derivatives $(S, S)-6$ and $(S, S)$-7, and 5,5-dioxophenothiazine derivatives $(S, S)-8-(S, S)-11$ were prepared starting from diamines $\mathbf{4}$ and $\mathbf{5}$, respectively, using the appropriate isocyanates and isothiocyanates (Fig. 2). The enantiomeric recognition abilities of bis(urea) and bis(thiourea) type receptors $(S, S)-\mathbf{6}-(S, S)-\mathbf{1 1}$ were studied toward the enantiomers of tetrabutylammonium salts of mandelic acid (Man), tert-butoxycarbonyl-protected phenylglycine (Boc-Phg), tert-butoxycarbonyl-protected phenylalanine (Boc-Phe) and tert-butoxycarbonyl-protected alanine (Boc-Ala). We proved that four of these enantiopure fluorescent receptor molecules containing $(S)$-1-arylethyl moieties could be applied as an- ion sensors for the recognition of the enantiomers of biologically important deprotonated carboxylic acid derivatives (Fig. 8). We demonstrated that the difference of urea and thiourea units had a great effect on the degree of enantiomeric recognition. ${ }^{25,26}$

Acridone derivative $(S, S)$-13 containing both amide and ester groups was prepared starting from acridone dicarboxylic acid $\mathbf{1 2}$ (Fig. 3). The crystal structure of $(S, S)$-13 was determined by X-ray crystallography. Fig. 9.A shows that $\mathrm{NH} \cdots \mathrm{O}$ type intramolecular bifurcated $\mathrm{H}$-bond was formed between the acridone $\mathrm{NH}$ and the amide oxygens. Sensor molecule $(S, S)$-13 showed selectivity toward $\mathrm{F}^{-}, \mathrm{Ca}^{2+}$ and $\mathrm{Hg}^{2+}$ (Fig. 10). While $\mathrm{F}^{-}$caused deprotonation of the sensor molecule, the latter forms complexes of different structures with $\mathrm{Ca}^{2+}$ and $\mathrm{Hg}^{2+}$. Using the optical responses of sensor molecule $(S, S)-\mathbf{1 3}$ for $\mathrm{F}^{-}$and $\mathrm{Ca}^{2+}$, we established double chemical input/single optical output molecular logic gates. Combinations of the particular molecular logic gates rendered molecular logic circuits, namely, a complementary IMP/INH circuit, a half-subtractor $(\mathrm{XOR} / \mathrm{INH})$ and a comparator $(\mathrm{XNOR} / \mathrm{INH})$, which could be operated by a single molecule and set of inputs. ${ }^{27}$

The syntheses of four unreported pyridine derivative precursors and new pyridino-crown ethers $(S, S)-\mathbf{1 4}-(S, S)$-16 containing a benzothiazole unit were carried out as outlined in Figs. 4 and 5 . The recognition abilities of crown ethers $(S, S)-\mathbf{1 4}-(S, S)$-16 were studied toward the enantiomers of hydrogen perchlorate salts of 1-phenylethylamine (PhEt), 1-(1-naphthyl)ethylamine (NapEt), phenylglycine methyl ester (PhgOMe) and phenylalanine methyl ester (PheOMe). Using fluorescence spectroscopy, we demonstrated that these crown ethers had moderate or appreciable enantiomeric recognition abilities toward the enantiomers of protonated primary amines. In the cases of crown ethers $(S, S)-\mathbf{1 5}$ and $(S, S)$ 16 and the selected protonated amino acid esters, we proved that the formation of protonated macrocycles took place in the excited state (Fig. 11.A). ${ }^{28}$

Eight new enantiomerically pure aza- and diaza-18-crown-6 ethers containing a pyrene fluorophore $[(R, R)-\mathbf{2 5}-(R, R)-\mathbf{2 8}$ and $(S, S)-\mathbf{2 5}-(S, S)-\mathbf{2 8}]$ and their unreported precursors were synthesized (Figs. 6 and 7). We proved that these crown ethers formed H-bonded complexes with the enantiomers of the above-mentioned hydrogen perchlorate salts of primary amines and amino acid esters, which resulted in large fluorescence enhancement due to the inhibition of the PET process. Diazacrown ethers $(R, R)-\mathbf{2 7}$ and $(S, S)-27$ containing an $N$-formyl group formed significantly more stable complexes with the studied protonated amino acid esters than with the protonated primary amines (Fig. 11.B) ${ }^{29}$

Some of the highlighted fluorescent receptors may be good candidates for incorporating them into polymeric membranes with the aim of constructing optical sensors. There is a great demand for the application of optical sensors in fields such as pharmaceutical industry, food industry, environmental protection, medical analysis, cell biology and process control. 